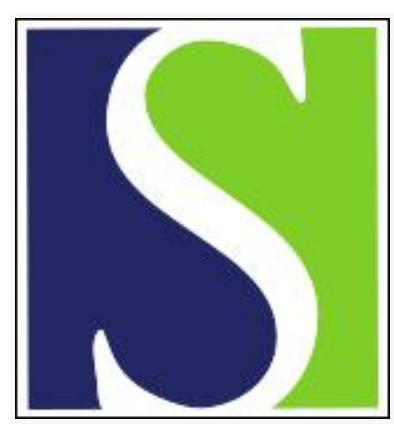

Scand J Work Environ Health 2000;26(5):427-435

https://doi.org/10.5271/sjweh.564

Issue date: Oct 2000

Renal and immunologic markers for chloralkali workers with low exposure to mercury vapor

by Ellingsen DG, Efskind J, Berg KJ, Gaarder PI, Thomassen Y

The following article refers to this text: 2006;32(3):241-249

Key terms: autoantibodies to myeloperoxidase; urinary $\mathrm{N}$-acetyl-beta-D-glucosaminidase

This article in PubMed: www.ncbi.nlm.nih.gov/pubmed/11103842

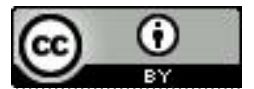




\title{
Renal and immunologic markers for chloralkali workers with low exposure to mercury vapor
}

\author{
by Dag G Ellingsen, MD, Jon Efskind, MD, ${ }^{1}$ Knut J Berg, MD, ${ }^{3}$ Per I Gaarder, MD, ${ }^{4}$ Yngvar Thomassen, \\ $M S c^{\dagger}$
}

\begin{abstract}
Ellingsen DG, Efskind J, Berg KJ, Gaarder PI, Thomassen Y. Renal and immunologic markers for chloralkali workers with low exposure to mercury vapor. Scand J Work Environ Health 2000;26(5):427-435.
\end{abstract}

\begin{abstract}
Objectives The aim of this study was to investigate renal function and immunologic markers among chloralkali workers with long-term low exposure to mercury vapor.

Methods Forty-seven currently exposed workers were compared with reference workers matched for age in a cross-sectional design.

Results The mean urinary mercury concentration was 5.9 (range 1.1-16.8) nmol/mmol creatinine (Cr) for the exposed workers and 1.3 (range $0.2-5.0) \mathrm{nmol} / \mathrm{mmol} \mathrm{Cr}$ for the referents. The chloralkali workers had been exposed for an average of 13.3 (range 2.8 -34.5) years. The activity of $\mathrm{N}$-acetyl- $\beta$-D-glucosaminidase in urine (U$\mathrm{NAG}$ ) was higher in the exposed workers (mean $0.18 \mathrm{U} / \mathrm{mmol} \mathrm{Cr}$ versus $0.14 \mathrm{U} / \mathrm{mmol} \mathrm{Cr}, \mathrm{P}=0.02$ ). Associations between current urinary mercury, cumulative urinary mercury, and cumulative urinary mercury per year (intensity) and U-NAG, autoantibodies to myeloperoxidase (anti-MPO) and proteinase 3 in serum, respectively, were observed. The activity of U-NAG and anti-MPO was increased in the workers with the highest exposure, as assessed by their mean intensity of exposure. The highest activity of U-NAG was observed in the exposed workers with the lower concentrations of selenium in whole blood.

Conclusions The study indicates an effect of exposure on the kidney proximale tubule cells, possibly modified by individual selenium status, and an effect mediated by neutrophil granulocytes.
\end{abstract}

Key terms autoantibodies to myeloperoxidase, urinary $\mathrm{N}$-acetyl- $\beta$-D-glucosaminidase.

The kidney is recognized as an important target organ for inorganic mercury toxicity. Toxic effects are related both to the proximal tubular cells and to changes at the level of the glomerular basement membrane (1). The latter changes have been attributed to immunologic mechanisms, which have been extensively studied in animals (2).

Cross-sectional studies of workers exposed to mercury vapor have indicated elevated activity of the kidney proximal tubular cell enzyme $\mathrm{N}$-acetyl- $\beta$-D-glucosaminidase in urine (U-NAG) or an association between U-NAG and mercury in urine (U-Hg) (3-7). Although an increased urinary excretion of albumin (UAlb), indicative of glomerular basement membrane affection, has been reported (8), most epidemiologic studies are nonpositive $(3-7,9-11)$. An increased prevalence of autoantibodies to the glomerular basement membrane (anti-GBM) has been reported for animals (mainly the Brown-Norway rat). Lympho proliferation, hyperimmunoglobulinemia (mainly immunoglobulin E), and autoantibody production (mainly anti-DNA) occur simultaneously (2). The induction of antinuclear antibodies (ANA) in mice has also been reported (12-14). Generally, transient immunologic alterations occur after exposure to mercuric chloride, and susceptibility is genetically controlled (2). Results from immunologic occupational studies on humans are ambiguous and in contrast to the experience gained from animal studies.

One study reporting an elevation of anti-GBM in humans $(10)$ is outweighed by several nonpositive reports $(3,6,7,15-17)$. Increased immunoglobulin $\mathrm{E}(\mathrm{IgE})$ was found in one study (18), but not in others $(7,16,19)$. The

1 National Institute of Occupational Health, Oslo, Norway.

2 Health Department, Borregaard Industries Ltd, Sarpsborg, Norway.

3 Section for Nephrology, Medical Department B, Rikshospitalet, Oslo, Norway.

4 Department of Immunology and Transfusion Medicine, Ullevål University Hospital, Oslo, Norway.

Reprint requests to: Dr Dag G Ellingsen, National Institute of Occupational Health, PO Box 8149 Dep, N-0033 Oslo, Norway. [E-mail: dag.ellingsen@stami.no] 
nonpositive studies of antibodies to deoxyribonucleic acid (anti-DNA) (16, 18-20) outweigh the positive ones (7). ANA have not been found $(6,16-20)$. The human kidney is rich in selenium (21), and the proximal tubule cells have been suggested to be the main source of plasma gluthathione peroxidase $(22,23)$. Selenium can reduce the kidney toxicity of inorganic mercury in animals (24), in particular in the proximal tubule cells (25). Increased lipid peroxidation with concomitant increased gluthathione peroxidase activity has been shown in kidneys of rats exposed to inorganic mercury (26). Selenium may also protect the kidney tubule cells in cancer patients receiving cis-platinum (27). These studies could suggest that individual selenium status may modify the toxic kidney effects of inorganic mercury. This study was performed to investigate renal function in chloralkali workers with long-term low exposure to mercury vapor with emphasis on detecting a no-effect level in particular. Furthermore, the study aimed at determining whether current or past exposure could be attributed to the studied effect measures, and finally whether individual selenium status may modify the possible effects of exposure to mercury vapor on the kidney.

\section{Subjects and methods}

\section{Study design and subjects}

Only men who had been exposed to mercury vapor for at least 1 year in a contaminated area of the plant under study were eligible for inclusion. Sixty-seven subjects working at the plant at the time of the examinations were identified. Four women, 5 workers exposed for less than 1 year, 4 subjects employed as administrative staff, and 3 subjects working outside the contaminated area were not included in the study. Fifty-one workers fulfilling the inclusion criteria constituted the target population. They were offered a voluntary medical examination after having received written information about the study.

The reference group comprised men employed by the same company at the same industrial complex. They were recruited from the cellulose bleaching, drying, and packing facilities and from the lignine drying and producing plant. They had no known current or past occupational exposure to mercury. The referents were offered the possibility to participate voluntarily in the medical examinations after having received written information about the study. They were matched for age ( \pm 3 years) with the exposed workers in pairs. A potential referent with the closest year and day of birth to the exposed subject who was to be matched was invited as the actual referent.

All 51 invited exposed workers attended the examinations (response rate $=100 \%$ ). For the match of these 51 workers, 56 referents had to be invited (response rate $=91.1 \%$ ). Exclusion criteria included alcohol abuse, major head injuries, metabolic disorders, and major psychiatric, neurologic or other diseases causing severe disability. Four exposed workers and 2 referents were excluded due to medical conditions (diabetes mellitus or vascular disorders of the brain). As the study design was based on pair-wise matching and 4 exposed workers were excluded, this report describes the results of 47 exposed workers and 47 referents.

All examinations, including a structured interview emphasizing occupational and medical history, sociodemographic background, and current alcohol consumption (28), were carried out at the local occupational health clinic. Background characteristics are shown in table 1.

\section{Exposure assessment}

The workers had been routinely monitored by measurements of their $\mathrm{U}-\mathrm{Hg}$ since the opening of the plant in 1949. Since the middle of the 1960 s cold-vapor atomic absorption spectrometry had been used for this purpose. The results from about 2200 measurements of $\mathrm{U}-\mathrm{Hg}$ were identified among the 47 included exposed workers (mean 2.9 measurements/worker annually). U-Hg was measured without correction for urinary creatinine until 1982. The mean of the individual urinary creatinine concentrations measured in 1982 and 1983 was used to correct the concentrations measured prior to 1982. We were not aware of the introduction of any other changes in the monitoring strategy at that time.

Table 1. Background characteristics, trace element concentrations in whole blood and urine, and exposure data for 47 male chloralkali workers in whole blood, $\mathrm{U}-\mathrm{Se}=$ selenium in urine, $\mathrm{B}-\mathrm{Cd}=$ cadmium in whole blood, $\mathrm{U}-\mathrm{Cd}=$ cadmium in urine, $\mathrm{Cum} \mathrm{U}-\mathrm{Hg}=$ cumulative index of

\begin{tabular}{|c|c|c|c|c|c|c|c|c|c|c|c|}
\hline \multirow[t]{2}{*}{ Group } & \multicolumn{2}{|c|}{ Age (years) } & \multicolumn{2}{|c|}{$\begin{array}{l}\text { Current alcohol } \\
\text { consumption } \\
\text { (I/year) }\end{array}$} & \multirow[t]{2}{*}{$\begin{array}{l}\text { Current smokers } \\
\qquad(\%)\end{array}$} & \multicolumn{2}{|c|}{$\begin{array}{c}\mathrm{U}-\mathrm{Hg} \\
\text { (nmol/mmol Cr) }\end{array}$} & \multicolumn{2}{|c|}{$\underset{(\mathrm{nmol} / \mathrm{A})}{\mathrm{B}-\mathrm{Hg}}$} & \multicolumn{2}{|c|}{$\begin{array}{l}\mathrm{B}-\mathrm{Hg}_{\mathrm{inorg}} \\
(\mathrm{nmol} / \mathrm{l})\end{array}$} \\
\hline & Mean & Range & Mean & Range & & Mean & Range & Mean & Range & Mean & Range \\
\hline Exposed & 42.0 & $24.0-66.8$ & 3.9 & $0-17.2$ & 53.2 & 5.9 & $1.1-16.8$ & 43.5 & $10.0-108.0$ & 20.7 & $2.5-65.0$ \\
\hline Referents & 41.9 & $23.3-64.2$ & 3.9 & $0-15.1$ & 34.0 & 1.3 & $0.2-5.0$ & 18.5 & $8.0-36.0$ & 5.7 & $2.5-18.0$ \\
\hline
\end{tabular}

46 subjects in each group (except 45 subjects for $\mathrm{B}-\mathrm{Hg}_{\mathrm{fnorg}}$ in the reference group).

b 46 subjects for U-Cd in the reference group. 
A cumulative index of exposure (Cum $\mathrm{U}-\mathrm{Hg}$ ), based on the historical U-Hg measurements, was calculated. The index was based on the worker's mean U-Hg for each quarter of the year. If a quarter was without $\mathrm{U}-\mathrm{Hg}$ measurements, a calculated value for that quarter was obtained as the mean of the U-Hg before and after the missing quarter. Based on these quarterly measurements, a mean $\mathrm{U}-\mathrm{Hg}$ for each year of exposure was calculated, and all years of exposure were added to yield the Cum $\mathrm{U}-\mathrm{Hg}$. Furthermore, an index of the mean intensity of exposure (Cum $\mathrm{U}-\mathrm{Hg} /$ year) was calculated by dividing Cum U-Hg by years of exposure. The concentrations of $\mathrm{U}-\mathrm{Hg}$ and inorganic mercury in whole blood $\left(\mathrm{B}-\mathrm{Hg}_{\text {inorg }}\right)$ at the time of examination were the indices used for current exposure. Exposure information is shown in table 1.

\section{Laboratory measurements}

First-voided morning urine was collected from the day before and the day of the examination in 25-ml NUNC@ containers (Nalge Nunc International, Denmark). The subjects were instructed to store the containers in a refrigerator. Trace elements were measured in the second sample. Blood specimens were obtained from the cubital vein. Heparinized whole blood for measurements of trace elements was collected in $10-\mathrm{ml}$ Venoject $®$ (Terumo Corporation, Belgium) tubes. Blood specimens for the determination of $\beta_{2}$-microglobulin and creatinine were collected in 7-ml Vacutainer(B SST tubes (Beckton and Dickinson, United States) and 5-ml Vacuette ${ }^{\circledR}$ tubes (Greiner Labortechnik, Austria), and 10-ml Vacuette ${ }^{\circledR}$ tubes for the immunologic assays. One subject refused to give a blood sample. All the samples were stored at $-20^{\circ} \mathrm{C}$ until the analysis.

\section{Renal markers}

Serum (centrifugation: 1500 revolutions/min for $10 \mathrm{~min}$ utes) and urine were stored in 4.5-ml NUNC(B cryo tubes. For the determination of alanin aminopeptidase (UAAP), $0.5 \mathrm{ml}$ of $87 \%$ glycerin was added to $4 \mathrm{ml}$ of urine. $\beta_{2}$-Microglobulin $\left(\mathrm{U}-\beta_{2}\right)$ was measured in urine adjusted at the time of the sampling with $1 \mathrm{~mol} / 1$ sodium hydroxide to a $\mathrm{pH}$ between 6.5 and 8 . Urine was stored for the determination of the other compounds without additives. All the measurements were carried out on day 60 after the sampling.

The serum concentrations of creatinine and $\beta_{2}$-microglobulin and the urine concentrations of creatinine, albumin, and enzymes were measured with a Cobas Mira analyzer (Cobas Instruments, Roche Diagnostic Systems, Switzerland) at $37^{\circ} \mathrm{C}(29)$. Creatinine was measured colorimetrically as an end-point measurement after 125 seconds at $500 \mathrm{~nm}$, using alkaline picrate (Unimate 7, Roche Diagnostic Systems, Switzerland). U-NAG [detection limit (DL) $0.02 \mathrm{U} / 1$ ] was measured colorimetrically based upon the release of 3-cresolsulfonphtalein from 3-cresol-sulfonpthaleinyl-N-acetyl- $\beta$-D-glucosaminide at $600 \mathrm{~nm}$, as an end-point measurement (Boehringer Mannheim, Germany). The within- and between-assay coefficient of variation (CV) was $2.8 \%$ and $3.0 \%$, respectively. U- $\beta_{2}$ was determined by a commercial radioimmunoassay kit (Pharmacia \& Upjohn, Sweden), the within- and between-assay coefficient of variation being 3.4\% and $6.0 \%$, respectively. Alkaline phosphatase in urine (UALP) was measured colorimetrically at $405 \mathrm{~nm}$ and a $\mathrm{pH}$ of 9.8 by a kinetic method as p-nitrophenol liberated from p-nitrophenyl phosphate (Boehringer Mannheim, Germany). The within- and between-assay coefficient of variation was $1.2 \%$ and $2.0 \%$, respectively. U-AAP (DL 0.5 $\mathrm{U} / \mathrm{l}$ ) was measured colorimetrically at $405 \mathrm{~nm}$ and a $\mathrm{pH}$ of 7.8 as an end-point analysis, based on the release of alanine-4-nitroanilide from alanine-4-nitroanilide-hydrochloride. The within- and between-assay coefficient of variation was $9.0 \%$ and $9.1 \%$, respectively. U-Alb (DL $0.02 \mathrm{mg} / \mathrm{l}$ ) was determined by an immunoturbidimetric method using a commercial kit as an end-point measurement at 340 nm (Unimate 3 alb, Roche Diagnostic System, Switzerland). The within- and between-assay coefficient of variation was $4.0 \%$ and $5.8 \%$, respectively.

Glycosaminoglycans in urine (U-GAG) was measured after precipitation with Alcian blue (30). The samples were mixed with a buffered solution of Alcian blue containing magnesium chloride and left overnight at room temperature. The complex formed was separated by centrifugation and dissociated in a solution of $7.5 \%$ sodium lauryl sulfate. The optical density was measured spectrophotometrically at $620 \mathrm{~nm}$ (within-assay CV

and 47 male referents. $\left(\mathrm{U}-\mathrm{Hg}=\right.$ mercury in urine, $\mathrm{B}-\mathrm{Hg}=$ mercury in whole blood, $\mathrm{B}-\mathrm{Hg} g_{\text {inorg }}=$ inorganic mercury in whole blood, $\mathrm{B}-\mathrm{Se}=\mathrm{selenium}$ exposure, Cum U-Hg/year = exposure intensity, $\mathrm{Cr}=$ creatinine)

\begin{tabular}{|c|c|c|c|c|c|c|c|c|c|c|c|c|c|}
\hline \multicolumn{2}{|c|}{$\begin{array}{c}\text { B-Se } \\
(\mu \mathrm{mol} / \mathrm{l})\end{array}$} & \multicolumn{2}{|c|}{$\begin{array}{c}\text { U-Se } \\
\text { (nmol/mmol Cr) }\end{array}$} & \multicolumn{2}{|c|}{$\begin{array}{c}\mathrm{B}-\mathrm{Cd} \\
(\mathrm{nmol} / \mathrm{I})\end{array}$} & \multicolumn{2}{|c|}{$\begin{array}{c}\text { U-Cd } \\
(\mathrm{nmol} / \mathrm{mmol} \mathrm{Cr})\end{array}$} & \multicolumn{2}{|c|}{$\begin{array}{l}\text { Cum U-Hg } \\
\text { (nmol/mmol Cr) }\end{array}$} & \multicolumn{2}{|c|}{$\begin{array}{c}\text { Cum U-Hg/year } \\
\text { (nmol/mmol Cr/year) }\end{array}$} & \multicolumn{2}{|c|}{ Years exposed } \\
\hline Mean & Range & Mean & Range & Mean & Range & Mean & Range & Mean & Range & Mean & Range & Mean & Range \\
\hline 1.48 & $1.06-2.52$ & 31.3 & $13.9-63.3$ & 5.8 & $0.5-19.7$ & 0.70 & $0.15-1.56$ & 123.2 & $14.5-490.6$ & 9.0 & $4.0-19.6$ & 13.3 & $2.8-34.5$ \\
\hline 1.47 & $0.81-2.23$ & 30.9 & $12.7-77.2$ & 5.4 & $0.5-20.0$ & 0.61 & $0.09-2.28$ & .. & .. &.. & .. & .. & .. \\
\hline
\end{tabular}


Table 2. Renal and immunologic markers for 47 male chloralkali workers currently exposed to mercury vapors and 47 male age-matched urine, U-NAG $=\mathrm{N}$-acetyl- $\beta$-D-glucosaminidase in urine, $\mathrm{U}-\mathrm{GAG}=$ glycosaminoglycanes in urine, U-Kal $=$ kallikrein in urine, anti-GBM = autoantibodies to proteinase 3 in serum, $\lg E=$ immunoglobulin $\mathrm{E}, \mathrm{Cr}=$ creatinine)

\begin{tabular}{|c|c|c|c|c|c|c|c|c|c|c|c|c|c|c|}
\hline \multirow[t]{3}{*}{ Group } & \multicolumn{14}{|c|}{ In urine } \\
\hline & $\begin{array}{r}\text { U-All } \\
(\mu \mathrm{g} / \mu \mathrm{mo}\end{array}$ & $(r)^{b}$ & $\begin{array}{r}\mathrm{U}-\beta_{2} \\
(\mu \mathrm{g} / \mathrm{mmol}\end{array}$ & $\mathrm{Cr})^{b}$ & $\begin{array}{r}\text { U-AL } \\
(\mathrm{U} / \mathrm{mmol}\end{array}$ & & $(U / n$ & $\begin{array}{l}\text { J-AAP } \\
\text { nmol }\end{array}$ & & $\begin{array}{c}\text { U-NAC } \\
(\mathrm{U} / \mathrm{mmol}\end{array}$ & & $\begin{array}{r}U-G A \\
(\mu g / \mu \mathrm{mo}\end{array}$ & & $\begin{array}{c}\text { U-Kal } \\
(\mathrm{U} / \mathrm{mmol} \mathrm{Cr})\end{array}$ \\
\hline & Mean SD & Range & Mean SD & Range & Mean SD & Range & Mean & SD & Range & Mean SD & Range & Mean SD & Range & Mean SD Range \\
\hline
\end{tabular}

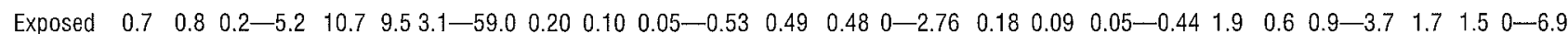

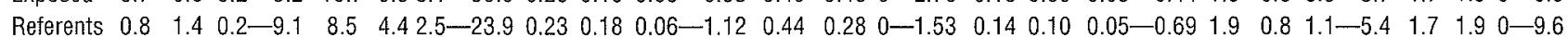

\begin{tabular}{llllllll}
\hline P-value & 0.42 & 0.22 & 0.80 & 0.77 & 0.02 & 0.82 & 0.92 \\
\hline
\end{tabular}

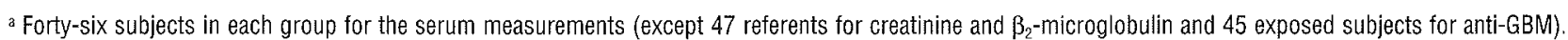

b Statistical comparisons performed on log-transformed variables.

4.7\%). Urinary kallikrein (U-Kal) (DL $0.0005 \mathrm{U} / 1$ ) was measured spectrophotometrically using the tripeptide $\mathrm{H}$ D-Val-Leu-Arg pNA as the substrate (AB Kabi, Sweden) (31). The within-assay coefficient of variation was $7.0 \%$.

\section{Immunologic assays in serum}

After centrifugation (1500 rpm for 10 minutes) serum was stored in NUNC@ $1.8-\mathrm{ml}$ cryo tubes. ANA, antiGBM, anti-MPO, and anti-PR3 were determined by Diastat $^{\text {TM }}$ ELISA kits (Shield, Scotland), according to the manufacturer's instructions. Immunoglobulin E (IgE) was assayed in a routine manner by the UniCAPTM system (Pharmacia \& Upjohn, Sweden).

\section{Measurements of trace elements}

The urine and whole blood samples were stored in NUNC ${ }^{\circledR}(25 \mathrm{ml})$ containers and 10 -ml Venoject ${ }^{\circledR}$ tubes, respectively, until the analysis.

Urinary mercury and total mercury in whole blood. Direct cold-vapor atomic absorption spectrometry was used to measure U-Hg (32). Total mercury in whole blood (B$\mathrm{Hg}_{\text {total }}$ ) was measured by the same instrumentation after nitric acid-hydrogen peroxide digestion ( $2 \mathrm{ml}$ of whole blood, $4 \mathrm{ml}$ of nitric acid, $0.5 \mathrm{ml}$ of hydrogen peroxide) in Teflon autoclaves.

Inorganic mercury in whole blood. The method for measuring $\mathrm{B}-\mathrm{Hg}_{\text {inorg }}$ has been described earlier (33). Whole blood $(0.5 \mathrm{ml})$ was added to $1.5 \mathrm{ml}$ of $95 \%$ sulfuric acid in glass tubes and heated for 16 hours at $65^{\circ} \mathrm{C}$ immediately after the mixing. It was then cooled to room temperature before dilution. Mercury was measured using the same instrumentation as for $\mathrm{B}-\mathrm{Hg}_{\text {total }}$ and $\mathrm{U}-\mathrm{Hg}$.

Cadmium and selenium in whole blood and urine. For the measurement of cadmium and selenium in whole blood (B-Cd and B-Se, respectively) $2.5 \mathrm{ml}$ of ultrapure $65 \%$ nitric acid was added to $2 \mathrm{ml}$ of whole blood in a polypropylene digestion tube. After degasification at room temperature overnight, the tube was heated at $95^{\circ} \mathrm{C}$ for 1 hour, cooled to room temperature, and diluted (13.7 $\mathrm{ml}$ ). Cadmium and selenium in urine (U-Cd and U-Se) were measured after dilution to $1: 1$ with $0.5 \%$ nitric acid. All the elements were measured by electrothermal atomic absorption spectrometry using a Perkin-Elmer Zeeman 5100 PC/HGA 600 system calibrated with whole-blood and urine-matched standard solutions.

\section{Accuracy and precision of the trace element measurements}

Accuracy and precision were assessed using Seronorm human whole blood (batches 107, 108 and 109) and urine (batch 4043125) reference materials (Sero Ltd, Asker, Norway). The day-to-day variations of $\mathrm{U}-\mathrm{Hg}(243 \mathrm{nmol} /$ $1), \mathrm{B}-\mathrm{Hg}_{\text {total }}(40 \mathrm{nmol} / \mathrm{l})$, and $\mathrm{B}-\mathrm{Hg}_{\text {inorg }}(39 \mathrm{nmol} / \mathrm{l})$ were typically $1.2 \%, 5 \%$, and $8 \%$, respectively. The results agreed well with the recommended values: U-Hg: 234 (SD 3) $\mathrm{nmol} / \mathrm{h}(\mathrm{N}=22)$ measured, $239 \mathrm{nmol} / \mathrm{l}$ recommended; B- $\mathrm{Hg}_{\text {total }}$ (3 levels): $14 \mathrm{nmol} / 1$ (SD 1) (N=9), 40 (SD 2) $\mathrm{nmol} / \mathrm{l}(\mathrm{N}=7)$ and $75(\mathrm{SD} 3) \mathrm{nmol} / \mathrm{l}(\mathrm{N}=7)$ measured, $15 \mathrm{nmol} / \mathrm{l}, 40 \mathrm{nmol} / \mathrm{l}$ and $70 \mathrm{nmol} / \mathrm{l}$, respectively, recommended. As no reference material was available for $\mathrm{B}-\mathrm{Hg}_{\text {inorg }}$, batch 108 was used for quality assurance $\left[\mathrm{B}-\mathrm{Hg}_{\text {inorg }} 39\right.$ (SD 3) nmol/l measured $\left.(\mathrm{N}=12)\right]$. No information on the content of inorganic mercury is given for this product. In the production of this material, a whole blood pool (identical to batch 107) was spiked with $25 \mathrm{nmol} / \mathrm{l}$ of bivalent mercury (batch 108). Measurement of the pool by the present method indicated that $11 \mathrm{nmol} /$ 1 out of the total mercury content of $15 \mathrm{nmol} / \mathrm{l}$ was present as inorganic mercury. The estimated concentration of $\mathrm{Hg}_{\text {inorg }}$ in batch 108 was thus $36 \mathrm{nmol} / \mathrm{l}(25+11)$. The detection limits $(3 \times$ standard deviation of the blank) were as follows: U-Hg: $2 \mathrm{nmol} / \mathrm{l}$; $\mathrm{B}-\mathrm{Hg}_{\text {total }}: 2 \mathrm{nmol} / \mathrm{l}$; $\mathrm{B}-\mathrm{Hg}_{\text {inorg }}: 5 \mathrm{nmol} / \mathrm{l}$. B-Hg $\mathrm{H}_{\text {inorg }}$ below the detection limit was set at $2.5 \mathrm{nmol} / \mathrm{l}$ for the data presentation. The average concentrations found for B-Cd (batch 107) and U-Cd (batch 101021) agreed with the recommended 
referents. (U-Alb $=$ urinary albumin, $\mathrm{U}-\beta_{2}=\beta_{2}$-microglobulin in urine, U-ALP $=$ alkaline phosphatase in urine, U-AAP $=$ alanin aminopeptidase in the glomerular basement membrane, anti-MPO = autoantibodies to myeloperoxidase in serum, ANA = antinuclear antibodies, anti-PR3 =

\begin{tabular}{|c|c|c|c|c|c|c|c|c|c|c|c|c|c|c|c|c|c|c|c|}
\hline \multicolumn{20}{|c|}{ In serum ${ }^{\hat{a}}$} \\
\hline \multicolumn{3}{|c|}{$\begin{array}{l}\text { Creatinine } \\
(\mu \mathrm{mol} / /)\end{array}$} & \multicolumn{3}{|c|}{$\begin{array}{c}\beta_{2}-\text { microglobulin } \\
(\mu \mathrm{g} / \mathrm{l})\end{array}$} & \multicolumn{3}{|c|}{$\begin{array}{c}\text { Anti-GBM } \\
(\mathrm{U} / \mathrm{ml})\end{array}$} & \multicolumn{3}{|c|}{$\begin{array}{c}\text { Anti-MPO } \\
(\mathrm{U} / \mathrm{m} \mathrm{l})^{\mathrm{b}}\end{array}$} & \multicolumn{2}{|c|}{$\begin{array}{c}\text { ANA } \\
(00 \text { ratio })^{b}\end{array}$} & \multicolumn{3}{|c|}{$\begin{array}{c}\text { Anti-PR3 } \\
(\mathrm{U} / \mathrm{m} /)^{\mathrm{b}}\end{array}$} & \multicolumn{3}{|c|}{$\underset{(U / m l)^{b}}{\lg E}$} \\
\hline Mear & $n$ SD & Range & Mean & SD & Range $N$ & Mean & SD & Range & Mean & $S D$ & Range & Mean SD & Range 1 & Mean & $n$ SD & Range $N$ & Mean & SD & Range \\
\hline 84.4 & 11.6 & $66.0-132.0$ & 1424 & 2379 & $985-1915$ & 1.17 & 0.16 & $0.92-1.68$ & 2.20 & 1.23 & $0.65-9.21$ & $\begin{array}{lll}1 & 0.53 & 0.13\end{array}$ & $0.33-0.93$ & 1.00 & 0.510 & $0.89-4.37$ & 75.0 & 139.2 & $1.0-661.0$ \\
\hline 85.1 & 8.3 & $68.0-106.0$ & 1403 & 2899 & $950-2575$ & 1,16 & 0.15 & $0.95-1.48$ & 1.90 & 0.51 & $1.39-3.56$ & $\begin{array}{lll}6 & 0.56 & 0.18\end{array}$ & $0.36-1.31$ & 0.92 & 0.030 & $0.88-1.00$ & 69.0 & 137.2 & $1.0-615.0$ \\
\hline 0.73 & & & 0.70 & & & 0.90 & & & 0.18 & & & 0.44 & & 0.26 & & & 0.69 & & \\
\hline
\end{tabular}

Table 3. Results from the stepwise multiple linear regression analysis for all the subjects. The exposure-related independent variables were entered separately in addition to age, smoking habits (grams/week), alcohol consumption (liters/year), selenium in urine, and selenium in whole blood. (U-NAG $=\mathrm{N}$-acetyl-b-D-glucosaminidase in urine, $\mathrm{B}-\mathrm{Se}=$ selenium in whole blood, $\mathrm{U}-\mathrm{Hg}=$ mercury in urine, Cum $\mathrm{U}-\mathrm{Hg}=$ cumulative index of exposure in urine, anti-MPO = autoantibodies to myeloperoxidase in serum, anti-PR3 = autoantibodies to proteinase 3 in serum, Cum U-Hg/year = exposure intensity)

\begin{tabular}{|c|c|c|c|c|c|}
\hline Dependent variable & Intercept & & Predictor variables & & $R$ \\
\hline U-NAG (log) & $=-0.71^{* \star *}$ & $-0.30^{* * *} \mathrm{~B}-\mathrm{Se}$ & $+0.006^{* *}$ Age & $+0.01 * \mathrm{U}-\mathrm{Hg}$ & $0.48^{* * *}$ \\
\hline U-NAG $(\log )$ & $=-0.77^{\star \star \star}$ & $-0.29^{\star \star} \mathrm{B}-\mathrm{Se}$ & $+0.007^{* *}$ Age & $+0.01 * *$ Cum U-Hg/year & $0.51^{\star \star \star}$ \\
\hline Anti-MPO (log) & $=0.24^{\star * *}$ & $+0.01^{* *} \mathrm{U}-\mathrm{Hg}$ & & & $0.32^{* *}$ \\
\hline Anti-MPO (log) & $=0.27^{\star \star \star}$ & $+0.01^{* *}$ Cum U-Hg/year & $-0.0006^{*}$ Smoking & & $0.35^{* *}$ \\
\hline Anti-MPO $(\log )$ & $=0.25^{\star \star \star}$ & $+0.001^{* * *}$ Cum U-Hg & & & $0.39^{* * *}$ \\
\hline Anti-PR3 (log) & $=-0.05^{\star \star \star}$ & $+0.007^{\star *} \mathrm{U}-\mathrm{Hg}$ & & & $0.35^{* *}$ \\
\hline Anti-PR3 $(\log )$ & $=-0.05^{\star \star *}$ & $+0.004^{\star *}$ Cum U-Hg/year & & & $0.32^{\star \star}$ \\
\hline Anti-PR3 (log) & $=-0.05^{* * *}$ & $+0.0004^{* * *}$ Cum U-Hg & & & $0.49 * * *$ \\
\hline
\end{tabular}

${ }^{* * *} P<0.001,{ }^{* *} P<0.01,{ }^{*} P<0.05$

values as follows: $\mathrm{B}-\mathrm{Cd}$ : 6.1 (SD 0.6) nmol/l $(\mathrm{N}=5)$ measured and $6 \mathrm{nmol} / \mathrm{l}$ recommended; U-Cd: 3.0 (SD 0.4) $\mathrm{nmol} / \mathrm{l}(\mathrm{N}=6)$ measured and $3.1 \mathrm{nmol} / 1 \mathrm{recommended.}$ The day-to-day variation was $10 \%$ and $13 \%$, respectively. The B-Se concentration measured in batch 108 was $1.05(\mathrm{SD} 0.06) \mu \mathrm{mol} / \mathrm{l}(\mathrm{N}=3)$ and that recommended was $1.04 \mu \mathrm{mol} / \mathrm{l}$. The corresponding U-Se concentration for batch 4043125 was $21.6(\mathrm{SD} 3.0) \mu \mathrm{g} / \mathrm{l}(\mathrm{N}=9)$ measured with no recommended value available from the producer.

\section{Statistics}

The mean concentrations of the urinary markers of renal toxicity of the 2 consecutive days are presented. Several of the measured variables had skewed distributions. They were log-transformed if the skewness exceeded 2.0 or if the distributions to be compared had different variances (Levene's test). An analysis of variance was used for the group comparisons. If more than 2 groups were compared, the least square difference was calculated post hoc to separate the groups that differed. General factorial analysis was used to control for the covariates. Associations between effect variables, exposure measures, and potential confounders [age, smoking habits (grams/ week), alcohol consumption (liters/year), B-Se, and U$\mathrm{Se}$ ] were assessed with a multiple linear regression analysis (backward procedure). The exposure measures (current $\mathrm{B}-\mathrm{Hg}_{\text {inorg }}$, current $\mathrm{U}-\mathrm{Hg}$, Cum U-Hg, and Cum U$\mathrm{Hg} /$ year) were entered separately into the models to avoid potential problems of collinearity. The level of statistical significance was set at $\mathrm{P}<0.05$ (2-tailed). The statistical package SPSS $®$, version 8.0 , was used.

\section{Results}

Table 2 shows the concentrations of the renal and immunologic markers for all the exposed subjects and referents. The U-NAG level was statistically significantly higher and the anti-MPO was nonsignificantly higher in the exposed group when it was compared with the reference group.

The U-NAG concentration was positively associated with U-Hg, Cum U-Hg/year, and age in the regression analysis (table 3 ). B-Se was negatively associated with U-NAG, a finding suggesting that higher B-Se was as- 
Table 4. Ratio between the geometric means and $95 \%$ confidence intervals for chloralkali workers exposed to mercury vapors and their age-matched referents for the activities of N-acetyl- $\beta$-D-gluco-saminidase in urine (U-NAG) (log) and autoantibodies to myeloperoxidase in serum (anti-MP0) (log) stratified according to the level of exposure as determined by current mercury in urine ( $\mathrm{U}-\mathrm{Hg}$ ), intensity of exposure (Cum $\mathrm{U}-\mathrm{Hg} / \mathrm{year}$ ) and cumulative index of exposure in urine (Cum $\mathrm{U}-\mathrm{Hg}$ ).

\begin{tabular}{|c|c|c|c|c|c|c|}
\hline & \multicolumn{2}{|c|}{ Low exposure $(\mathrm{N}=15)$} & \multicolumn{2}{|c|}{ Medium exposure $(\mathrm{N}=16)$} & \multicolumn{2}{|c|}{ High exposure $(\mathrm{N}=16)$} \\
\hline & Ratio & $95 \% \mathrm{Cl}$ & Ratio & $95 \% \mathrm{Cl}$ & Ratio & $95 \% \mathrm{Cl}$ \\
\hline \multicolumn{7}{|c|}{$\mathrm{U}-\mathrm{Hg}(\mathrm{nmol} / \mathrm{mmol} \mathrm{Cr})^{\mathrm{a}}$} \\
\hline U-NAG & 1.06 & $0.72-1.58$ & 1.39 & $1.04-1.86$ & 1.41 & $1.02-1.94$ \\
\hline Anti-MPO & 0.91 & $0.72-1.15$ & 1.0 & $0.79-1.26$ & 1.44 & $1.14-1.82$ \\
\hline \multicolumn{7}{|c|}{ Cum U-Hg/year (nmol/mmol Cr/year) $)^{b}$} \\
\hline U-NAG & 0.96 & $0.64-1.46$ & 1.32 & $0.98-1.75$ & 1.59 & $1.14-2.20$ \\
\hline Anti-MPO & 0.94 & $0.73-1.20$ & 1.11 & $0.90-1.38$ & 1.46 & $1.12-1.89$ \\
\hline \multicolumn{7}{|c|}{ Cum U-Hg $(\mathrm{nmol} / \mathrm{mmol} \mathrm{Cr})^{\mathrm{c}}$} \\
\hline U-NAG & 1.22 & $0.88-1.72$ & 1.10 & $0.73-1.64$ & 1.51 & $1.12-2.04$ \\
\hline Anti-MPO & 0.87 & $0.68-1.13$ & 1.11 & $0.90-1.38$ & 1.43 & $1.12-1.83$ \\
\hline
\end{tabular}

a For low exposure mean 2.7 , range $1.1-3.7$; for medium exposure mean 4.6 , range $3.8-5.6$; and for high exposure mean 10.0 and range $5.8-16.8$.

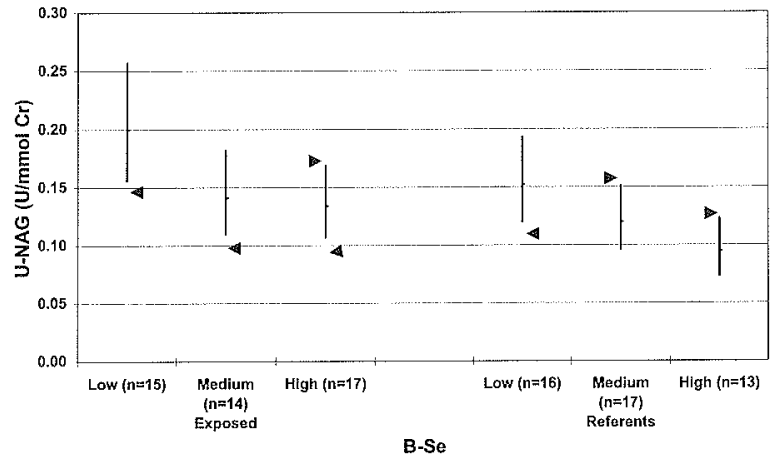

Figure 1. The activity of $\mathrm{N}$-acetyl- $\beta$-D-glucosaminidase in the urine $(\mathrm{U}$ $N A G)$, expressed as the mean and $95 \%$ confidence interval, of chloralkali workers exposed to mercury vapor and referents stratified according to selenium in whole blood (B-Se) $(\mathrm{Cr}=$ creatinine, low B-Se $<1.38$ $\mu \mathrm{mol} / /, \mathrm{N}=31$; medium $\mathrm{B}-\mathrm{Se}=1.38-1.56 \mu \mathrm{mol} / \mathrm{l}, \mathrm{N}=31$; high $\mathrm{B}-\mathrm{Se}$ $>1.56 \mu \mathrm{mol} / \mathrm{l}, \mathrm{N}=30$ ). Arrows above the bars indicate a P-value of $<0.05$ when the exposed workers with low B-Se were used as referents. Arrows below the bars indicate a P-value of $<0.05$ when referents with high B-Se were used as reference.

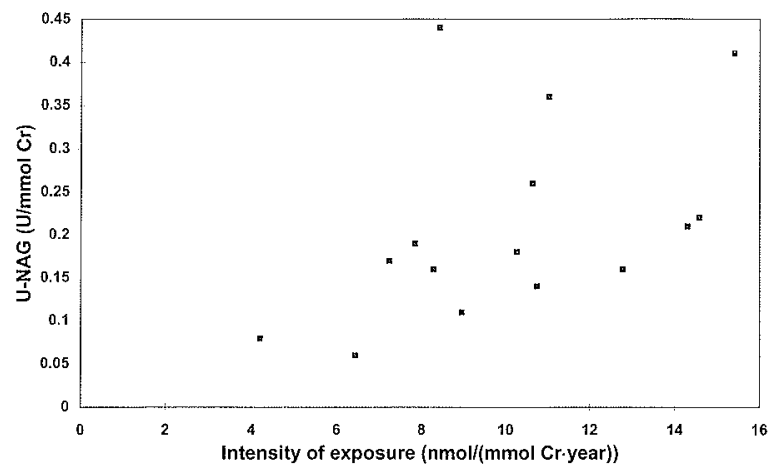

Figure 2. Relation between $\mathrm{N}$-acetyl- $\beta$-D-glucosaminidase in urine (U-NAG) and the intensity of exposure to mercury vapor for 15 chloralkali workers with low selenium levels in their blood (Spearman's $r=0.55, P=0.03)$. ( $\mathrm{Cr}=$ creatinine)

sociated with lower U-NAG. U-Cd did not contribute to the models when added as a predictor. Both anti-MPO and anti-PR3 were positively associated with $\mathrm{U}-\mathrm{Hg}$, Cum
$\mathrm{U}-\mathrm{Hg} /$ year, and Cum U-Hg. The exposure measures were not associated with any of the other markers.

The exposed workers were stratified into 3 equally large groups according to the different exposure measures and compared with their corresponding age-matched referents (table 4). With the aid of the results from the regression analysis, U-NAG was adjusted for B-Se and age, and anti-MPO was adjusted for smoking habits. The difference is expressed as a ratio and $95 \%$ confidence interval $(95 \% \mathrm{CI})$, because the variables were log-transformed (34). Both U-NAG and anti-MPO were higher in the highest exposure subgroups. The concentrations were similar for the workers with low levels of exposure and their referents. U-NAG was also higher in the exposed subjects with medium current U-Hg levels. No significant differences between the groups emerged for antiPR3.

U-NAG was associated with B-Se in the regression analysis, and this finding suggests that U-NAG activity decreases as the B-Se increases. Figure 1 presents U-NAG (adjusted for age) for the subjects stratified into 3 equally large groups according to their current B-Se level ("high", "medium", and "low") and, further, according to their exposure status. The lowest U-NAG value was measured for the group of referents in the high B-Se group, whose B-Se level differed statistically significantly from those of all the other groups, except the referents with a medium B-Se level. The highest U-NAG was found for the exposed subjects with a low B-Se level. These subjects differed from the exposed subjects with high $(\mathrm{P}=0.022)$ and medium $(\mathrm{P}=0.056) \mathrm{B}-\mathrm{Se}$ and from the referents with low $(\mathrm{P}=0.11)$, medium $(\mathrm{P}=0.003)$ or high $(\mathrm{P}<0.001) \mathrm{B}-\mathrm{Se}$. An association between $\mathrm{U}$ NAG, age $(\mathrm{P}=0.03)$, and $\mathrm{B}-\mathrm{Se}(\mathrm{P}=0.02)$ was also found for the reference group [U-NAG $(\log )=-0.77+0.006$ age - $0.27 \mathrm{~B}-\mathrm{Se}$. An association was found between Cum U-Hg/year and U-NAG (Spearman's $r=0.55, \mathrm{P}=0.03$ ) for the exposed subjects with low B-Se (figure 2), but not 
for the exposed subjects with high or medium B-Se. None of the other exposure measures or age was statistically significantly associated with U-NAG in this subgroup (not shown).

High correlations were found between $\mathrm{U}-\mathrm{Alb}$ and $\mathrm{U}$ NAG (Spearman's $r=0.54, \mathrm{P}<0.001$ ) and between antiMPO and anti-PR3 (Spearman's $r=0.60, \mathrm{P}<0.001$ ), respectively, for the exposed workers. Anti-MPO and antiPR3 were not significantly associated with U-NAG or U-Alb.

\section{Discussion}

The main finding in this study was that the exposed workers had higher U-NAG levels than the referents. An increased U-NAG level was mainly detected in the exposed subjects with "high" current U-Hg or "high" past exposure. An association between U-NAG and exposure to mercury vapor has been shown previously $(3-7)$. The subjects in this study, however, were exposed to lower current levels of mercury vapor, as indicated by their U$\mathrm{Hg}$ concentration. Their previous exposure was also low, as their mean U-Hg of $9.0 \mathrm{nmol} / \mathrm{mmol} \mathrm{Cr}$ during their 13.3 years of exposure indicates. Hence this study may suggest that U-NAG as a marker of potential kidney proximal tubular cell toxicity is increased at lower mercury exposure (as assessed by current $\mathrm{U}-\mathrm{Hg}$ ) than previously recognized.

U-NAG in first voided morning urine from 2 consecutive days was measured because of the considerable dayto-day variation in U-NAG excretion. The Spearman's $r$ between day 1 and day 2 was $0.48(\mathrm{P}<0.001)$, and using the mean activity from 2 consecutive days reduced the coefficients of variation from $69 \%$ and $71 \%$ to $60 \%$ and thereby increased the statistical power. U-NAG is unstable when stored at $-20^{\circ} \mathrm{C}$. After 2 weeks or 2 months of storage, the measured activities were reported to decrease by $13 \%$ and $25.6 \%$, respectively (29). All the urine samples were therefore measured 2 months after the sampling to avoid biased results. Generally, exposed subjects are sampled before the referents in cross-sectional studies with matched designs. Measuring all the urine at the same time thus could have resulted in an underestimation of effect.

Four exposure measures were used. B-Hginorg, probably reflecting the most recent exposure, was not associated with the U-NAG level. The remaining measures were based on the U-Hg concentration and were probably related to the accumulation of mercury in the kidneys. Cum $\mathrm{U}-\mathrm{Hg} /$ year appeared to discriminate better than current $\mathrm{U}-\mathrm{Hg}$ between the exposed subjects and the referents, whereas Cum $\mathrm{U}-\mathrm{Hg}$ was not associated with the U-NAG concentration. Cum U-Hg/year was also the only exposure measure associated with U-NAG in the low B-Se group. The number of persons in this study was, in our opinion, too few to indicate which exposure measure is the most appropriate predictor of the detected increase in U-NAG.

B-Se was negatively associated with U-NAG, and an increased U-NAG was mainly found in exposed subjects with low B-Se levels. Selenium has protective properties against untoward effects of inorganic mercury exposure on animals $(24,25)$, but little is known for humans. U-NAG is considered a marker of toxicity of the kidney proximal tubular cells in the absence of gross glomerular basement membrane defects. These cells are the major source of extracellular gluthathione peroxidase, which indicates the demand for selenium $(22,23)$. The observation made of increased lipid peroxidation with a concomitant increase in gluthathione peroxidase activity in the kidney and an increased kidney proximal tubulus cell enzyme $\gamma$-glutamyl transferase for rats exposed to inorganic mercury could be important in this context $(26,35$, 36). One could speculate that the accumulation of mercury could affect the amount of selenium required by gluthathione peroxidase for handling increased lipid peroxidation. At this low exposure level, most of the subjects had sufficient selenium to eliminate the possible effects of exposure, except those with "low" B-Se. It is in this context significant that patients administered another well-known selenium antagonist platinum, and who also received selenium in high doses, had a significantly lower increase of U-NAG than patients who did not receive selenium (27). The selenium concentration in serum is comparatively high in Norwegian adults (37), and the suggested possible modifying effects of selenium could perhaps indicate that other populations with lower $\mathrm{B}-\mathrm{Se}$ may be more vulnerable to the effects of exposure to mercury vapor with respect to U-NAG.

The increased activity of U-NAG was slight, and above the laboratory reference $(0.026-0.284 \mathrm{U} / \mathrm{mmol} \mathrm{Cr}$ in samples frozen at $-20^{\circ} \mathrm{C}$ for 2 months) in 3 referents and 6 exposed workers. The sensitive indicator of brush border toxicity (U-AAP) was not increased, and this finding could indicate the origin of the changes. The longterm consequences are not well known, but one epidemiologic study on formerly exposed chloralkali workers suggests that an increased U-NAG level may be reversible (38). Our study did not reveal an increased concentration of U-Alb, and this result is in accordance with the findings of several other epidemiologic studies (37, 9-11).

Anti-MPO was significantly higher in the highest exposed workers than in their age-matched referents. Furthermore, anti-PR3 was associated with several measures of exposure. The current smokers' concentrations of anti-MPO were similar to those of the current nonsmokers $(\mathrm{P}=0.30)$. Only 1 exposed worker had anti-MPO and 
anti-PR3 levels above the cutoff level (both weakly positive). Proteinase 3 of neutrophil granulocytes and anti-PR3 is strongly associated with Wegeners granulomatosis, a severe necrotizing vasculitis (39). Myeloid peroxidase is also a product of neutrophil granulocytes (39), and anti-MPO is clinically associated with autoimmune vasculitis, mainly in the kidneys. The high correlation (Spearman's $r=0.60, \mathrm{P}<0.001$ ) between these 2 autoantibodies in the exposed group could be an indication of the common origin in the neutrophil granulocytes of the 2 substances. We are not familiar with other studies of these markers in humans exposed to mercury vapor. However, a 4-fold increase in the activity of myeloperoxidase was found in isolated glomeruli of rats exposed to mercuric chloride when they were compared with control rats (40). When interpreting our results in this context, one could speculate that the exposed workers may have acquired a tendency toward vasculitis, perhaps in the renal vasculature. Both thickening of the wall and vasoconstriction (36) of renal blood vessels have been reported for rats exposed to mercuric chloride. It has been suggested that mesangial hyperplasia, compressing the capillary tuft, may result in ischemia (40). AntiGBM, however, reacting with glomerular antigens on collagen type IV, was not increased, and this finding is in accordance with the results of previous studies $(3,6$, $7,15-17)$. No association was found between anti-MPO or anti-PR3 and U-Alb or U-NAG, respectively. The clinical importance of the exposure-associated increased activity of the immunologic markers, if any, remains to be elucidated.

The exposed subjects and the referents were similar with respect to several background variables (eg, age and current alcohol consumption). However, smoking was more prevalent in the exposed group, but without being associated with U-NAG. All the examined workers were also employees at the same industrial complex, the referents working only a few hundred yards away from the exposed workers. The effects reported in this study would hardly be noticed by the exposed subjects, and therefore the potential general disadvantage of cross-sectional studies (ie, selection of subjects who become ill due to exposure out of the work force) was minimized. The high participation rates further indicate that selection bias may have been of little importance.

In conclusion, this study suggests that even low, but long-term, exposure to mercury vapor can induce untoward effects in the kidney proximal tubule cells, as assessed by the activity of U-NAG. It appears that selenium, assessed by B-Se, may modify the increase. Furthermore the study showed increased levels of anti-MPO and possibly also anti-PR3. These autoantibodies against constituents of neutrophil granulocytes could possibly be indicators of an inflammatory process in vascular structures, perhaps in the kidney.

\section{Acknowledgments}

The study was financially supported by Borregaard Ind Ltd, the Borregaard Fund for Medical Research, and Eurochlor.

\section{References}

1. World Health Organization (WHO). Inorganic mercury. Geneva: WHO, 1991. Environmental health criteria, no 118.

2. Druet P, Pelletier L, Rossert J, Druet E, Hirsch F, Sapin C. Autoimmune reactions induced by metals. In: Kammüller ME, Bloksma N, Seinen W, editors. Autoimmunity and toxicology. Amsterdam: Elsevier, 1989:347—61.

3. Stonard MD, Chater BV, Duffield DP, Nevitt AL, O'Sullivan JJ, Steel GT. An evaluation of renal function in workers occupationally exposed to mercury vapour. Int Arch Occup Environ Health 1983;52:177-89.

4. Barregård L, Hultberg B, Schütz A, Sällsten G. Enzymuria in workers exposed to inorganic mercury. Int Arch Occup Environ Health 1988;61:65-9.

5. Ehrenberg RL, Vogt RL, Smith AB, Brondum J, Brightwell WS, Hudson PJ, et al. Effects of elemental mercury exposure at a thermometer plant. Am J Ind Med 1991;19:495-507.

6. Langworth $S$, Elinder CG, Sundquist KG, Vesterberg O. Renal and immunological effects of occupational exposure to inorganic mercury. Br J Ind Med 1992;49:394-401.

7. Càrdenas A, Roels H, Bernard AM, Barbon R, Buchet JP, Lauwerys RR, et al. Markers of early renal changes induced by industrial pollutants, I: application to workers exposed to mercury vapour. Br J Ind Med 1993;50:17-27.

8. Buchet JP, Roels H, Bernard A, Lauwerys R. Assessment of renal function of workers exposed to inorganic lead, cadmium or mercury vapour. J Occup Med 1980;22:741—9.

9. Roels H, Lauwerys R, Buchet JP, Bernard A, Barthels A, Oversteyns $\mathrm{M}$, et al. Comparison of renal function and psychomotor performance in workers exposed to elemental mercury. Int Arch Environ Health 1982;50:77-93.

10. Lauwerys R, Bernard A, Roels H, Buchet JP, Gennart JP, Mahieu P, et al. Anti-laminin antibodies in workers exposed to mercury vapour. Toxicol Lett 1983;17:113-6.

11. Piikivi $L$, Ruokonen $A$. Renal function and long-term low mercury vapor exposure. Arch Environ Health 1989;44:1469.

12. Hultman $P$, Eneström S. Mercury induced antinuclear antibodies in mice: charcterization and correlation with renal immune complex deposits. Clin Exp Immunol 1988;71:26974.

13. Mirtcheva J, Pfeiffer C, De Bruijn JA, Jacquesmart F, Gleichmann $\mathrm{E}$. Immunological alterations inducible by mercury compounds, III: $\mathrm{H}-2 \mathrm{~A}$ acts as an immune response and $\mathrm{H}-2 \mathrm{E}$ as an immune "suppression" locus for $\mathrm{HgCl}_{2}$-induced antinucleolar autoantibodies. Eur J Immunol 1989;19:2257-61.

14. Hultman P, Eneström S. Mercury induced B-cell activation and antinuclear antibodies in mice. J Clin Lab Immunol $1989 ; 28: 143-50$.

15. Bernard AM, Roels HR, Foidart JM, Lauwerys RL. Search for anti-laminin antibodies in the serum of workers exposed to cadmium, mercury vapour or lead. Int Arch Occup Environ Health 1987:59:303-9.

16. Langworth S, Elinder C-G, Sundqvist K-G. Minor effects of 
low exposure to inorganic mercury on the human immune system. Scand J Work Environ Health 1993;19:405-13.

17. Barregård L, Eneström S, Ljunghusen $\mathrm{O}$, Wieslander J, Hultman P. A study of autoantibodies and circulating immune complexes in mercury-exposed chloralkali workers. Int Arch Occup Environ Health 1997;70:101-6.

18. Dantas DCM, Queiroz LS. Immunoglobulin E and autoantibodies in mercury-exposed workers. Immunopharmacol Immunotoxicol 1997;19:383-92.

19. Soleo L, Vacca A, Vimercati L, Bruno S, Di Loreto M, Zocchetti C, et al. Minimal immunological effects on workers with prolonged low exposure to inorganic mercury. Occup Environ Med 1997;54:437-42.

20. Ellingsen DG, Gaarder PI, Kjuus H. An immunological study of chloralkali workers previously exposed to mercury vapour. APMIS 1994;102:170-6.

21. Högberg J, Alexander J. Selenium. In: Friberg L, Nordberg DF, Vouk VB, editors. Handbook on the toxicology of metals, vol 2. Amsterdam: Elsevier, 1986:482-520.

22. Avissar N, Ornt DB, Yagil Y, Horowitz S, Watkins RH, Kerl EA, et al. Human kidney proximal tubules are the main source of plasma glutathione peroxidase. Am J Physiol 1994;266 (Cell Physiol 35):C367-C375.

23. Whitin JC, Tham DM, Bhamre S, Ornt DB, Scandling JD, Tune BM, et al. Plasma glutathione peroxidase and its relationship to renal proximal tubule function. Mol Genet Metab 1998:65:238-45.

24. Parizek J, Ostadalova I. Protective effects of small amounts of selenite in sublimate intoxication. Experientia 1967;23:1423.

25. Lindh $U$, Johansson E. Protective effects of selenium against mercury toxicity as studied in the rat liver and kidney by nuclear analytical techniques. Biol Trace Elem Res 1987; 12:109-20.

26. Girardi G, Elias MM. Mercuric chloride effects on rat renal redox enzymes activities: SOD protection. Free Radic Biol Med 1995;18:61-6.

27. Hu YJ, Chen Y, Zhang YQ, Zhou MZ, Song XM, Zhang BZ, et al. The protective role of selenium on the toxicity of cisplatin-contained chemotherapy regimen in cancer patients. Biol Trace Elem Res 1997;56:331-41.

28. Hauge R, Irgens-Jensen O. Alkoholen i Norden [Alcohol in the Nordic countries]. Alkoholpolitik 1987;4 suppl:48-9.

29. Berg KJ, Kristoffersen DT, Djøseland O, Hartmann A, Bre- istein $\mathrm{E}$, Lund $\mathrm{KK}$, et al. Reference range of some enzymes and proteins in untimed overnight urine and their stability after freezing. Clin Chim Acta 1998;272:225-30.

30. Whiteman $P$. The quantitative measurement of Alcian Blue glycosaminoglycan complexes. Biochem J 1973;131:34350 .

31. Amundsen E, Putter J, Friberger $\AA$, Knøs M, Larsbråten M, Claeson G. Methods for determination of glandular kallikrein by means of chromogenic tripeptide substrate. Adv Exp Med Biol 1979;120A:83-95.

32. Ellingsen DG, Holland RI, Thomassen Y, Landro-Olstad M, Frech W, Kjuus H. Mercury and selenium in workers previously exposed to mercury vapour at a chloralkali plant. $\mathrm{Br} \mathrm{J}$ Ind Med 1993;50:745-52.

33. Bergdahl IA, Schütz A, Hansson G-Å. Automated determination of inorganic mercury in blood after sulfuric acid treatment using cold vapour atomic absorption spectrometry and an inductively heated gold trap. Analyst 1995;120:1205-9.

34. Gardner MJ, Altman DG. Calculating confidence intervals for means and their differences. In: Gardner MJ, Altman DG, editors. Statistics with confidence - confidence intervals and statistical guidelines. London: British Medical Journal, 1989: $20-7$.

35. Girardi G, Elias MM. Effectiveness of N-acetylcysteine in protecting against mercuric chloride-induced nephrotoxicity. Toxicol 1991;67:155-64.

36. Girardi G, Elias MM. Evidence for renal ischaemia as a cause of mercuric chloride nephrotoxicity. Arch Toxicol 1995 69:603-7.

37. Nève $\mathbf{J}$. Methods in determination of selenium states. $\mathbf{J}$ Trace Elem Electrolytes Health Dis 1991;5:1-17.

38. Ellingsen DG, Barregård L, Gaarder PI, Hultberg B, Kjuus H Assessment of renal dysfunction in workers previously exposed to mercury vapour at a chloralkali plant. $\mathrm{Br} \mathrm{J}$ Ind Med 1993;50:881-7.

39. Janeway Jr CA, Travers $P$, Hunt $S$, Walport M. Immunobiology: the immunesystem in health and disease. London, New York: Current Biology Ltd, Garland Publishing Inc; 1997.

40. Girardi G, Saball DE, Salvarrey MS, Elías MM. Glomerular compromise in mercuric chloride-induced nephrotoxicity. J Biochem Toxicol 1996;11:189-96.

Received for publication: 21 October 1999 